\title{
Evaluation of Four Methods for Restoring a Degraded Swamp Forest
}

\author{
Gisele Mondoni Marconato1, Rita C. S. Maimoni-Rodella², Claudia Mira Attanasioº \\ ${ }^{1}$ School of Forest Science, Unesp Botucatu, Sao Paulo, Brazil \\ ${ }^{2}$ Department of Botany, Institute of Biosciences of Botucatu, UNESP Botucatu, São Paulo, Brazil \\ ${ }^{3}$ Sao Paulo Agency for Agribusiness Technology (APTA/SAA-SP), São Paulo, Brazil \\ Email: giselemarconato@yahoo.com.br
}

Received 20 April 2015; accepted 11 May 2015; published 15 May 2015

Copyright (C) 2015 by authors and Scientific Research Publishing Inc.

This work is licensed under the Creative Commons Attribution International License (CC BY). http://creativecommons.org/licenses/by/4.0/

(c) (i) Open Access

\begin{abstract}
Swamp Forests occur in permanently wet soils, with specific ecosystem which contributes to the conservation of biodiversity and water resources. However, there are many gaps in knowledge about the restoration of these forests. The present study was conducted in a degraded wetland in the town of Mineiros do Tietê, located in the state of São Paulo, Brazil, in order to test the efficiency of four methods for restoring a Swamp Forest (small mound, acclimated seedling, dry season and conventional tillage), using six forest tree species typical of this type of forest: Calophyllum brasiliense Cambess., Citharexylon myrianthum Cham., Cedrela odorata L., Tapirira guianensis Aubl., Ficus insipida Willd. and Croton urucurana Baill. The least favorable methods for all plant species were: conventional and soil pit tillageindry seasons. Analyzing the plant species individually, the best results in descending order were: Croton urucurana Baill. (acclimated seedling tillage in dry season), followed by Calophyllum brasiliense Cambess. (insmall mounds), Citharexylon mirianthum Cham. (with acclimated seedlings), Ficus insipida Willd. and Tapirira guianensis Aubl. (insmall mounds). Cedrela odorata L. presented low performance in all conditions, probably because it suffered the Hypsipyla grandella Zeller. The results have been successful for the establishment of Swamp Forest restoration strategies.
\end{abstract}

\section{Keywords}

Restoration Methods, Acclimatization, Soil Water Saturation, Riparian Zone

\section{Introduction}

Swamp Forests are common in hydromorphic soils with permanent occurrence of superficial water. Therefore,

How to cite this paper: Marconato, G. M., Maimoni-Rodella, R. C. S., \& Attanasio, C. M. (2015). Evaluation of Four Methods for Restoring a Degraded Swamp Forest. Open Journal of Forestry, 5, 500-509.

http://dx.doi.org/10.4236/ojf.2015.55043 
they are naturally fragmented and present structural, floristic and physiognomic particularities which differ from other forest types, including the Riparian Forest, or Gallery Forest which are temporarily subjected to soil water saturation (Torres et al., 1994; Ivanauskas et al., 1997; Toniatto et al., 1998, Teixeira et al., 2008). Swamp Forests are located in riparian areas which carry out an essential function on hydrological, ecological, and geomorphic processes. They keep the hydrographic micro watershed and the aquatic ecosystem healthy and resilient (Naiman \& Décamps, 1997; Agnew et al., 2006; Allan et al., 2008; Burkhard et al., 2010; Attanasio et al., 2012; Matthews, 2013).

These forests carry essential role to the pursuit of sustainable development through the protection and maintenance of water resources and biodiversity. Therefore, the conservation, the study, and the improvement of methods for its restoration require special attention, especially in the current context of global discussions about the importance of protecting the environment for the quality of life of human beings (Ramsar Convention, 1971; Collins et al., 2013; Conference United Nations Conference on Environment and Development, "ECO-92”, 1992; the World Summit on Sustainable Development, Johannesburg, South Africa, "Rio + 10", in 2002, the "Rio + 20”, 2012, are some examples).

In this paper, the definition of assumed ecological restoration is that presented by the Society for Ecological Restoration International (SER International; SER 2002; www.ser.org) and adopted by the International Union for the Conservation of Nature (IUCN): ecological restoration is the process of assisting the recovery of an ecosystem which was and has been degraded, damaged or destroyed.

Restoration methods have been tested to reverse the degrading condition; however, they are never meant for swampy areas, even though they are highly degraded and have extremely particular characteristics (Rodrigues et al., 2009).

In Swamp Forests, the permanent occurrence of soil water saturation represents a great difficulty for their restoration; therefore, it is important to carry out researches on the restoration, monitoring, dynamics and regeneration of this type of vegetation.

Some authors (Zedler, 2003; Rodriguez and Leitão-Filho, 2004; Rodrigues \& Gandolfi, 2004) highlighted the necessity of intensifying the research development for restoring wetland areas since the government and farmers restoring initiatives are scarce or not so thriving, leading to a considerable biodiversity loss besides endangering the water resource quality.

The Convention on Wetlands of International Importance, called The Ramsar Convention (Irã), which took place in 1971, is an intergovernmental treaty which provides the framework for national action and international cooperation for the conservation and wise use of wetlands and their resources. One of the main goals exposed in documents resulting from The Ramsar Convention is to aware people of the benefits of the planet's wetlands. (Matthews, 2013; http://www.ser.org/programs/global-partnerships/ramsar-convention-on-wetlands).

Floristic and phytosociological surveys carried out in areas with remnants of Swamp Forests subsidize the selection of species for restoration actions (Torres et al., 1994; Ivanauskas et al., 1997; Toniatto et al., 1998; Joly et al., 2004; Teixeira \& Assis, 2005).

Given that context, the importance of the development of studies on the restoration of Swamp Forests becomes clear, since there are many aspects to be investigated, especially when it comes to methods and specific techniques for conducting the practice of ecological restoration in water saturation areas.

This study aimed to evaluate four methods for restoring Swamp through the analysis of survival and development of six typical species of this forest type to obtain scientific information which may contribute to broadening the knowledge boundaries about the restoration of these areas, to provide grants and technical guidance for extension work, rural farmers and nurserymen, and to public politics that aimed at the conservation of water resources and biodiversity.

The hypothesis is that the methods for restoration which were developed for this research in order to minimize the seedling initial stress owing to permanent changes of soil water saturation, should present better results than conventional method. Considering the species selected for testing, the expectation was that they would have different performances due to the behavior they present in the reference ecosystem.

\section{Materials and Methods}

\subsection{Study Area}

This project was accomplished at Farm Santa Fé, in a degraded swampy area, located in the watershed of the 
River São João (22 $26^{\prime} 15.40^{\prime \prime S}$ and $\left.48^{\circ} 27^{\prime} 11.28^{\prime \prime W}\right)$ in the town of Mineiros do Tietê (São Paulo, Brazil) (Figure 1).

About 10 years ago, this site, which had been drained and cultivated with pasture, was abandoned presenting a soggy ground characteristic, having its area occupied by invasive grass (Urochloa decumbens (Stapf.) RD Webster).

According to Setzer \& Malingreau (1996), the region's climateis hot with dry winters. In the driest month, rainfall reaches, on average, $30 \mathrm{~mm}$, while in the hottest month, the maximum temperature exceeds $22^{\circ} \mathrm{C}$ and in the coldest month, it is below $18^{\circ} \mathrm{C}$.

\subsection{Species Selection}

The tree species were selected based on floristic lists of regional native species typical of Swamp Forests (Campos et al., 2011; Marques et al., 2003; Paschoal \& Cavassan, 1999; Toniato et al., 1998, Ivanauskas, 1997, Oliveira-Filho \& Ratter, 1995; Torres et al., 1994), as well as on their availability in nurseries, the following were selected: Calophyllum brasiliense Cambess. (Clusiaceae family), Citharexylum myrianthum Cham. (Verbenaceae family), Cedrela odorata L. (Meliaceae family), Tapirira guianensis Aubl. (Anacardiaceae family), Ficus insipida Willd. (Moraceae family) and Croton urucurana Baill. (Euphorbiaceae family).

\subsection{Methods}

Four restoration methods were implemented and evaluated: 1) conventional method: the seedlings were planted in pits with dimensions of $30 \mathrm{~cm} \times 30 \mathrm{~cm} \times 30 \mathrm{~cm}$, dug at the ground level, in the traditional way; 2) small mound (or inverted pits) method: the seedlings were planted on small mounds of soil $30 \mathrm{~cm}$ high by $70 \mathrm{~cm}$ wide; therefore, staying raised from the saturated soil surface; 3 ) acclimated seedling in nurseries method: the seedlings received a treatment before being planted, stayed for 43 days in an environment with gradual water saturation, and then the tillage was done in pits as in the conventional model; 4) planting during the dry season
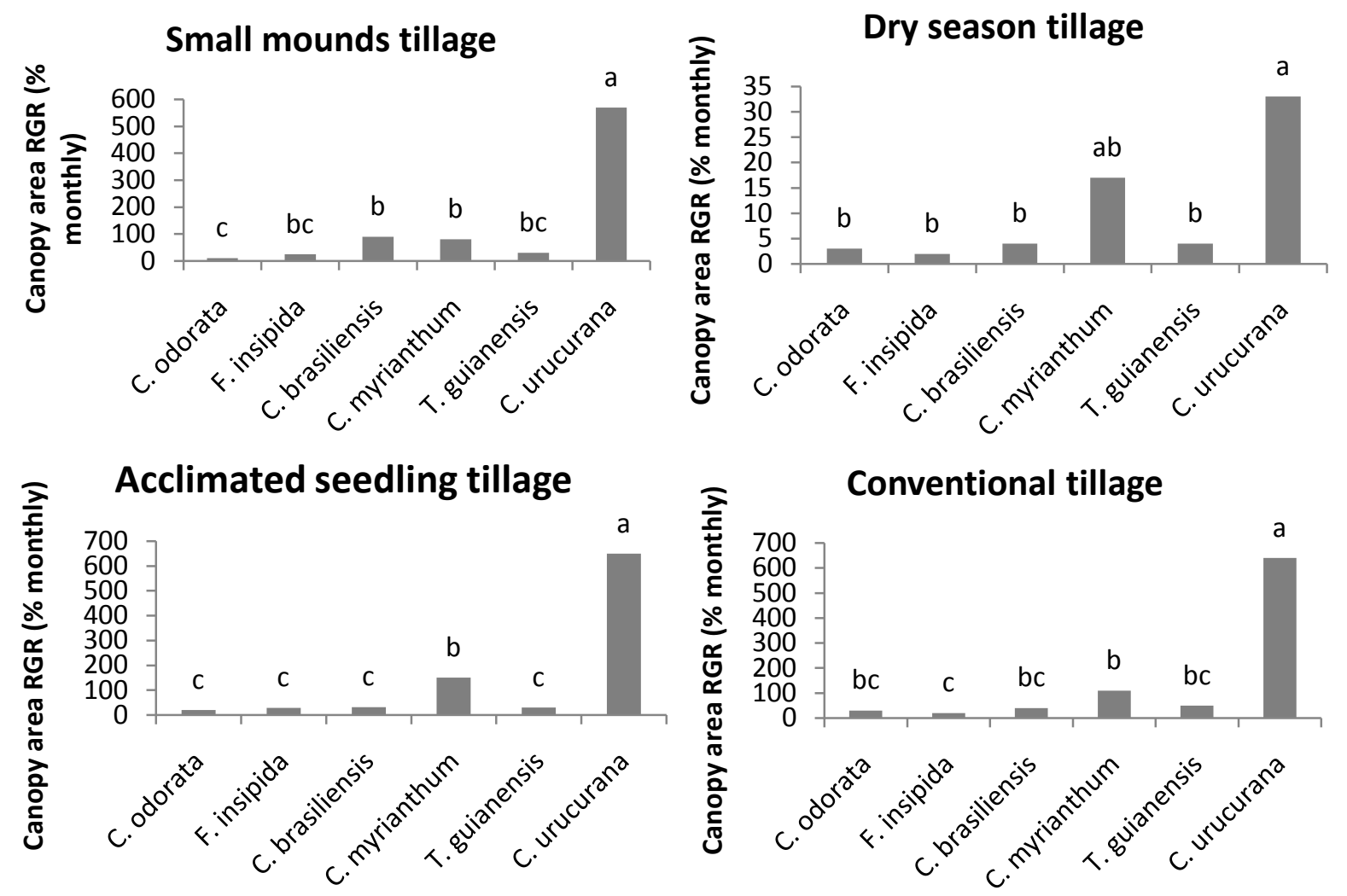

Figure 1. Average relative growth rate (RGR) for height increment of six tree species grown under four methods of tillage in a Swamp restoration area. 
of the year, held four months after installing the first three treatments, with a less water-saturated soil due to the decrease of rainfall occurs in winter months.

In the acclimation method, the seedlings were kept in the nursery for 43 days in a tank with water, covered with a protection screen against direct solar radiation, with a 50\% reduction. The tank was filled with water in three stages, adding $1 / 3$ of its volume every 13 days on the first two stages. When it reached the maximum volume, and the seedlings were covered with water up to the neck, they remained in the tank for another 17 days. So, they were selected according to health and uniformity, and taken to the experiment installation area to be planted in pits, as in the conventional model.

The methods were designed to minimize the stress of seedlings due to soil water saturation, as observed in field experience with conserved Swamp Forests.

Procedures - In February, after cleaning the land, the project was implemented for the first three procedures. In July, the dry season method was implemented. The experiment occupied the area of $6400 \mathrm{~m}^{2}$ and it was outlined in randomized blocks, in subdivided plots with four replications, testing the four restoration methods for the six selected species.

When the experiment was being implemented, the seedlings were about nine months and an average of 0.65 $\mathrm{m}$ high. Each method was implemented in a plot of $18 \mathrm{~m} \times 25 \mathrm{~m}$, in which the species were distributed after the randomization. A border without planting of $2.0 \mathrm{~m}$ was kept between plots and blocks. About 60 seedlings, 10 of each species, were planted in each plot with a spacing of $2 \mathrm{~m} \times 3 \mathrm{~m}$ between the seedlings, following an order that was repeated consecutively.

There was not any soil correction or fertilization made. During the first year, the control of invasive plants was performed every three months by mechanized mowing in line, hand-weeding of the lines, and manual crowning of the seedlings. Maintenance was made every six months from the end of the first year and during the second one.

\subsection{Survival and Growth Evaluation}

The monitoring was carried out every two months for over 25 months (from March 2008 to March 2010) by observing the survival and development of the plants which were considered dead when they were without leaves and with the stem visibly dry. Each plant was evaluated in height (distance from the ground to the apical stem) and canopy area (ground cover), which was calculated by using the equation of the ellipse area:

$(\mathrm{D} \times \mathrm{d} \times \pi) / 4$, where $D=$ the largest diameter and $d=$ the largest transverse diameter related to $D$.

The Relative Growth Rate (RGR) was obtained for each plant and parameter, and expressed as an average per species in every tillage method, aiming to minimize the effect of the plant size at the beginning of the experiment which was calculated according to the equation used by Zamith \& Scarano (2006):

$$
\operatorname{RGR}=[(\mathrm{M} / \mathrm{Mi}) / \Delta \mathrm{t}-0.05] 100
$$

where Mf (final measurement), Mi (initial measurement) and $\Delta \mathrm{t}$ (difference in months between the two measurements).

The data were compared by variance analysis with a subsequent average comparison by using the Tukey test at $5 \%$ probability and when necessary, the transformation of the original data for variances homogeneity was performed.

Based on Zamith \& Scarano (2006), two rates were used and obtained from the survival and growth data in order to perform comparisons among species and tillage methods according to the efficiency in the restoration process performance, which is the Growth Index (GI)) and the Use Viability Index (UVI).

The GI was calculated according to the equation:

$$
\mathrm{GI}(\mathrm{i})=(\mathrm{Pa}(\mathrm{i})+\mathrm{Pac}(\mathrm{i})) /(\mathrm{Pa}(\max )+\mathrm{Pac}(\max ))
$$

Where Pa(i) and Pac(i) are awarded points (from the smallest to the largest growth) for each species according to the statistically significant differences in RGR in height and canopy area, respectively. The awarded points ranged from 1 to 5 in height and from 1 to 4 for the canopy area, and Pa (max) and Pac (max) the maximum possible values for each parameter.

The UVI was used to integrate the values of the growth rate and survival percentage in a single value, as idealized by Zamith \& Scarano (2006), calculated by using the equation UVI(i) = GI(i) $\times$ PS(i), where: PS(i) is the 
percentage of each species survival, at the end of 25 months for the first three tillage methods and at the end of 21 months for the dry season tillage.

\section{Results}

\subsection{Survival}

At the end of the first year, there was low mortality for all the species in the four tillage forms, being registered $80 \%-100 \%$ survival of planted seedlings. However, at the end of the second year, there was lower survival and it was observed that some values were much lower than these (Table 1), in which the overall average of the four methods was approximately $71 \%$.

The small mound method and acclimated seedling in nursery method were the way that presented better survival results, in which half of the evaluated species had rates higher than 90\% (Table 1).

Although the initial expectations were positive, the planting during the dry season was not successful, even with the decrease in soil water saturation. In this method, half of all evaluated species presented lower survival rates compared to all other tillage forms and no species reached higher values. This also occurred with the conventional method, although in this case it was already expected.

The species $C$. brasiliense and $C$. urucurana presented, after two years in conventional method on small mounds and acclimated seedlings in nursery, values between $90 \%$ and $100 \%$.

C. odorata did not obtain good performance in any method. This result probably occurred mainly by the Hypsipyla grandella Zeller (Lepidoptera, Pyralidae) on seedlings, whose larvae feed on the apical meristem, causing stunted growth which generally culminates with death of plants.

\subsection{Growth Index and Relative Growth Rate}

Overall, the growth, expressed by GI, was lower under conventional and planting during the dry season method (Table 1).

The best results were obtained by small mound and acclimated seedling methods. The species with higher GI submitted to small mound method were $C$. brasiliense, F. insipida and T. guianensis. In acclimated seedling method C. urucurana and C. myrianthum presented higher GI (Table 1).

The highest height RGR occurred with C. brasiliensein conventional and small mound methods (Figure 1). However, there was no significant difference among C. brasiliense, F. insipida, C. myrianthum and T. guianensis in conventional method and among $C$. brasiliense, $F$. insipida, $T$. guianensis and $C$. urucurana in small mound method. $C$. odorata had the lowest rate of height growth in all conditions; however, it was not significantly different from $F$. insipida and C. urucurana in conventional method and C. myrianthum in small mound method. In acclimation method, growth rates were generally lower, and there was no significant difference among the species, except for $C$. odorata, which differed significantly from all others. In planting during the dry season, there was no significant difference among species (Figure 1).

The canopy growth rate was significantly higher for $C$. urucurana in comparison with other species in the four methods (Figure 2), presenting a high performance except when method was done during the dry season,

Table 1. Percent survival (\%S), growth index (GI), and use viability index (UVI) of six tree species grown under four methods of tillage for restoring degraded Swamp areas. UVI bold $>50$.

\begin{tabular}{|c|c|c|c|c|c|c|c|c|c|c|c|c|}
\hline \multirow{2}{*}{ Species } & \multicolumn{3}{|c|}{ Conventional tillage } & \multicolumn{3}{|c|}{ Small mounds } & \multicolumn{3}{|c|}{ Acclimated seedling tillage } & \multicolumn{3}{|c|}{ Dry season tillage } \\
\hline & $\% \mathrm{~S}$ & GI & UVI & $\% \mathrm{~S}$ & GI & UVI & $\% \mathrm{~S}$ & GI & UVI & $\% \mathrm{~S}$ & GI & UVI \\
\hline C. odorata & 17.8 & 0.33 & 5.87 & 65.9 & 0.28 & 18.45 & 22.7 & 0.40 & 9.08 & 31.8 & 0.50 & 15.90 \\
\hline F. insípida & 62.5 & 0.44 & 27.50 & 95.2 & 0.71 & 67.59 & 67.5 & 0.60 & 40.50 & 65.5 & 0.50 & 32.75 \\
\hline C. brasiliensis & 90.9 & 0.77 & 69.99 & 97.7 & 0.85 & 83.05 & 97.7 & 0.60 & 58.62 & 72.7 & 0.50 & 36.35 \\
\hline C. myrianthum & 60.0 & 0.77 & 46.20 & 80.0 & 0.57 & 45.60 & 97.5 & 0.80 & 78.00 & 52.5 & 0.75 & 39.37 \\
\hline T. guianensis & 56.8 & 0.66 & 37.49 & 79.5 & 0.71 & 56.45 & 65.9 & 0.60 & 39.54 & 61.4 & 0.50 & 30.70 \\
\hline C. urucurana & 97.7 & 0.66 & 64.48 & 97.7 & 0.85 & 83.05 & 100.0 & 1.00 & 100.00 & 86.4 & 1.00 & 86.40 \\
\hline
\end{tabular}




\section{Dry season tillage}
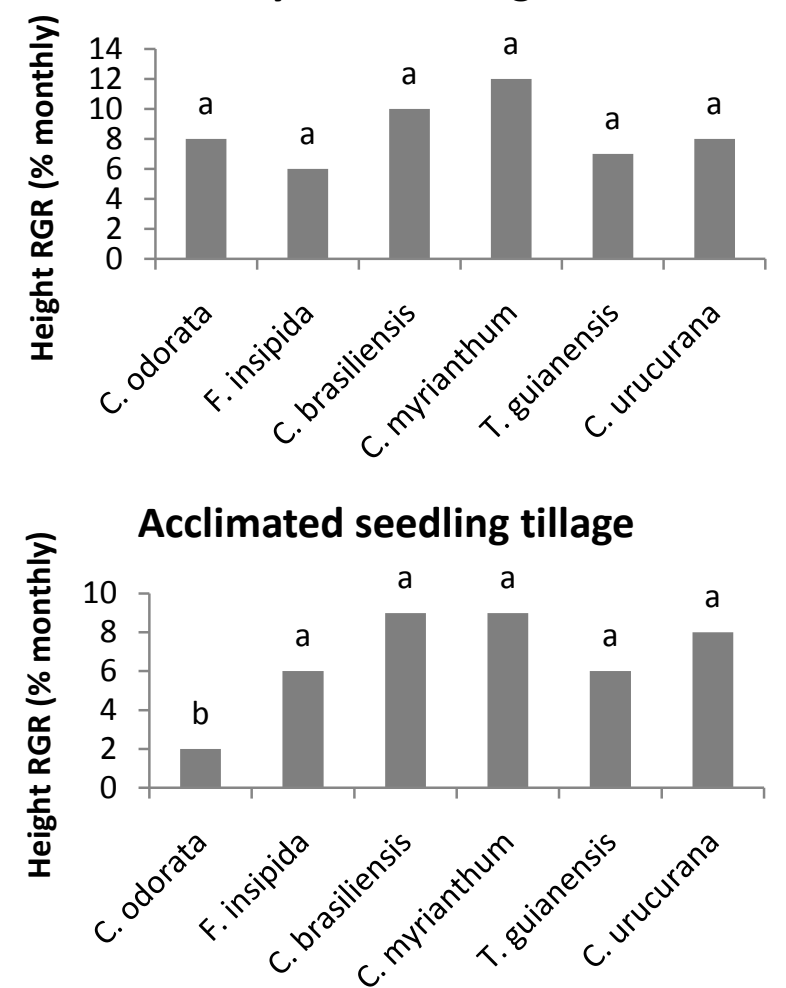

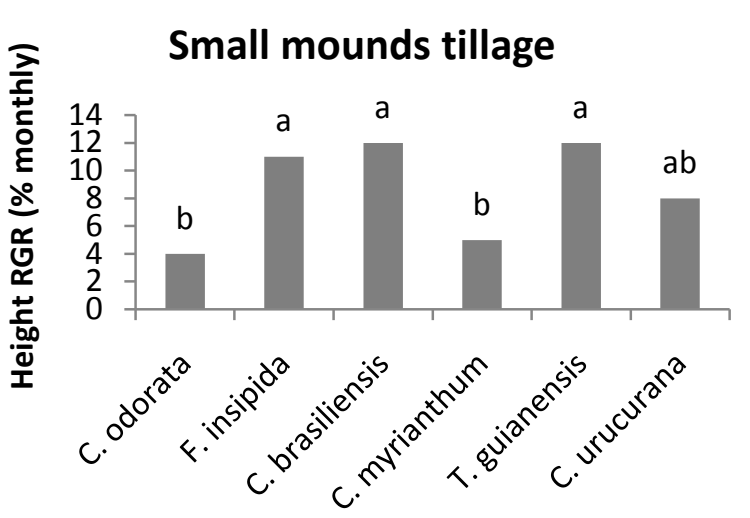

Conventional tillage

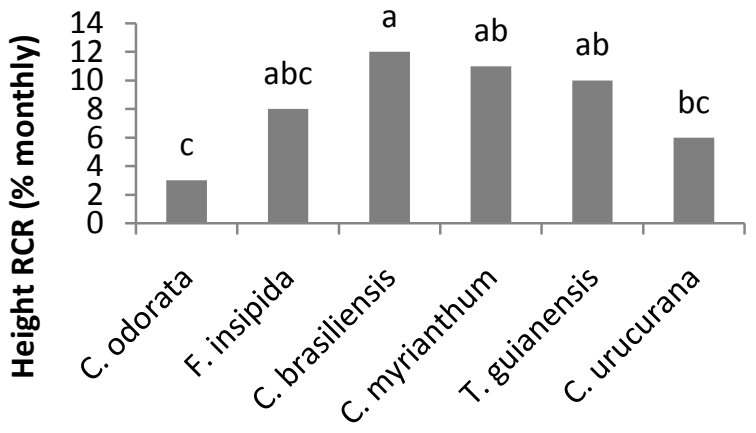

Figure 2. Average relative growth rate (RGR) for canopy area increment of six tree species grown under four methods of tillage in a Swamp restoration area.

which did not differ from C. myrianthum significantly.

During the dry season method, the RGR of the canopy area was much smaller for all species in comparison with the other tested methods.

\subsection{Use Viability Index (UVI) in Restoration Initiatives}

The UVI integrates the growth and survival index. The small mound method and acclimated seedling method were, in the present study, the most promising methods according to the UVI in restoration initiatives. These two methods also presented the highest survival values and the largest GI, for almost all species. So, they are recommended for restoration actions in Swamp Forests (Table 1).

The best results in UVI were obtained in descending order for $C$. urucurana in acclimated seedling and in planting during the dry season methods, followed by C. brasiliense for small mound method, C. myrianthum with acclimated seedlings and $F$. insipida, $T$. guianensis for small mound method (Table 1).

It was observed that $C$. odorata had a very low performance in all tested conditions, probably due to the Hypsipyla grandella Zeller. This is a species which often occupies the floristic lists compiled for Swamp Forest, so it can still be considered promising when restoring this vegetation.

\section{Discussion}

The results of the present study indicate that there is a promising potential for the restoration of degraded Swamp Forests through of methods developed specifically for this type of degraded area.

At the end of the second year, the survival rate of the four methods evaluated, had an overall average estimated at $71.7 \%$. According to methods, the estimates of average survival were $86 \%$ for small mound method, $75.4 \%$ for acclimated seedling method, $61.7 \%$ for planting during the dry season method and $64.2 \%$ to conventional method.

Zamith \& Scarano (2006) presented the results of a study on the restoration of salt marshes in which they 
evaluated 17 species of typical trees and shrubs of this type of vegetation and monitored the survival and growth of 20 plants by species for 2 years. Despite the hardships imposed by nutrient-poor soil, $70 \%$ of the species had high survival percentage (greater than $80 \%$ ) and considerable growth.

Among the methods evaluated in this study, the highest values of survival, GI and UVI were generally observed in small mound method (inverted pits).

The positive results of small mound method are probably related to the fact that in Swamp Forests, which occur in low and flat lands with irregular micro-relief, characterized by numerous small submerged elevations ("small mounds") of dimensions ranging between approximately 0.20 and $0.50 \mathrm{~cm}$-high and 0.5 to $2.0 \mathrm{~m}$-diameter. Those are the "small mounds" where most individuals of this flora establish themselves naturally (Toniato et al., 1998).

In a study carried out by Marques \& Joly (2000, 2002), the mortality of Callophyllum brasiliense Cambess. in flooded areas, was higher among seedlings and decreased in subsequent classes, mainly caused by the burial that smaller species suffered due to the entrainment of organic matter and soil by water from streams during the rainy season (Marques \& Joly, 2002). In preserved swampy areas there have been observed plants growing on hillocks (accumulations of dirt or sand) or on bogs (accumulation of organic matter), or on natural small mounds, where the neck region of the plant, as well as part of its roots, are not in direct contact with water (Sztutman \& Rodrigues, 2002).

Although small mound method has presented a really promising restoration action, it presents a lower yield in soil management, requiring greater financial investment in workforce especially during maintenance.

Galindo and colleagues (2012) have presented their results on a practical assessment of "silvotermiteros" which are small mounds for planting tree species in wetlands, in intensive silvopasture systems, in Venezuela. According to the authors, the small mounds fulfilled the function of providing a well-drained micro-field for plants, favoring adaptation and accelerating the development in its early stages.

The acclimation in seedlings in the nursery proved to be very favorable for the beginning of the restoration of a Swamp Forest. Resistance and tolerance of a species in water saturated areas is not only conditioned by its survival, but also for its development and growth in anoxic conditions (Kozlowski, 1984). The soil saturation produces ecophysiological answers, morphological and anatomical changes, such as hypertrophy of lenticels, adventitious rooting and development of parenchyma at the base of stems and rhizomes. These changes were observed during the acclimation in seedlings and are generally associated with an increase in diffusion capacity of $\mathrm{O}_{2}$ from aerial parts to roots. The $\mathrm{O}_{2}$ deficiency occurs at the level of rhizosphere due to the water soil saturation (Joly \& Crowford, 1982).

Studies must be carried out to determine the most suitable period of time for the water saturation of seedlings in the nursery, considering the adaptive particularities of each species, how this process must be conducted, which species best adapt to this procedure, which water saturation techniques are easy to be implemented and conducted at low cost to be developed on a large scale in nurseries. Such research could contribute with some interesting recommendations for nurserymen, both technically and financially.

As previously mentioned, small mound method raise the process costs. Thus, the development of a suitable acclimation method to be applied in nurseries would be very convenient considering the results obtained. This shows that such studies need to continue.

Regarding the growth, the performance was also promising, with the exception of $C$. odorata.

Within each method evaluated, the height Relative Growth Rate of species did not differ significantly in their majority. The same happened with the canopy area, with the exception of $C$. urucurana. Therefore, it is possible to say that the different species generally had a similar response when subjected to a method.

At Zamith \& Scarano's work (2006) nine out of the 17 species showed no significant increase in height and some species showed reduced canopy area due to deciduousness or broken branches.

In the present study, the dry season method, as an alternative of restoration action, was not very promising. The development of the seedlings until March 2010 showed that they did not reach the same levels of UVI compared to those obtained in small mound and acclimated seedling methods, probably because it had a shorter period of data collection.

Also, in the dry season of the year, the seedlings in the nurseries are not always in their proper development stage to be planted. In order to apply this method, the seedlings must be previously ordered, specifically for this season of the year.

Croton urucurana presented the highest UVI among the studied species, especially in acclimated seedling 
method. The intensive growth of its canopy classifies this species as highly promising for situations when rapid shading of the soil is required, as a strategy to prevent grass invasion and other typically halophytic weeds. These results are in accordance with Gorenstein et al. (2006), who reports these species as the best developed in height and canopy projection in recovering experiment of riparian forest. Lorenzi (2008), describes this species as a pioneer; selective hygrophytes which characterizes wet and swampy lands, especially in riparian formations of the semi-deciduous broadleaf forest.

Calophyllum brasiliense presented the second best performance. The $C$. brasiliense tolerance to the soil water saturation, as well as its ability to survive and grow in flooded soil, have been pointed out and recommended by Marques \& Joly (2000), for restoration programs in swampy areas. The results of the study by Teixeira et al. (2008) presented that Calophyllum brasiliense was one of the most abundant species in their floristic surveys in Swamp Forests.

The Cytharexylum myrianthum had the third best performance. It is a halophytic species, selective hygrophytes which characterizes gallery and Atlantic rain forests, it preferably occurs in very wet and swampy land, in dense ombrophilous forests and in the riparian areas of semi-deciduous seasonal forests (Carvalho, 1994; Lorenzi, 2008).

The species T. insipida, Cedrela odorata, and Ficus insipida have a slower development, however, they are necessary for the biodiversity formation of a mature Swamp Forest.

Zamith \& Scarano (2006) have recommended the use of four species (Senna australis, Pseudobombax grandiflorum, Chamaecrista ensiformis and Tapirira guianensis) for restoring the open salt marsh on the west side of the Rio de Janeiro (Brazil), which had growth rates between 0.69 and 0.67 and UVI between 65.6 and 87.0. Furthermore, these species were more tolerant to high temperatures and wind.

Considering that species diversity is one of the important plant communities attributes which affects the ecosystems balance directly (Zamith \& Scarano, 2006; Rodrigues et al., 2011), and that the differential performance of these species is essential in forest restoration, the results obtained here with these species are positive for the restoration of Swamp Forests and they are consistent with the initial hypothesis.

It is necessary to perform experiments which can clarify the benefits of alternative methods of wetland restoration (Zedler, 2003), and this study example with good initial results for restoring Swamp Forests in Brazil. Although a small number of species has been assessed, it indicates that there are promising prospects to restore the biodiversity and tropical ecosystem processes of Brazil and other countries.

\section{Conclusions}

In following researches on Swamp Forests restoration, studies which may present a list of recommended methods for different situations are important, depending on, for instance, the characteristics of the area to be restored, the structural and financial conditions of the rural producer and the region infrastructure.

It would be also interesting to evaluate other native species of Swamp Forests, considering the importance of maintaining and restoring this vital ecosystem, its biodiversity and its ecological processes.

It is suggested that further research, considered essential for the Swamp Forest restoration, should approach the seedling transplant as a restoring action, as well as cuttings, direct seeding and others. Studies on ecological succession and the adaptive mechanisms of typical species of this ecosystem would be equally important in order to enable the ecological processes recovering and the greatness of this forest type.

In addition, the long-term monitoring of the study area as well as the implementation of monitoring permanent plots for preserved Swamp Forests and restoration areas in this ecosystem will provide immensely valuable answers. That will enable practical actions for their protection and restoration as well as the basis for long term related research.

It is important to remember that these studies may support public policies for the protection and restoration of typical wetland forests.

\section{Implications for Practice}

Based on practical experience and the results of this research, the authors of this article recommend the following to those who have the difficult task of restoring Swamp Forests or wetlands:

- Instead of making use of soil pits for tillage, plant the seedlings of Swamp Forest typical species on small mounds of soil approximately $30 \mathrm{~cm}$ high and $70 \mathrm{~cm}$ wide, so that their roots will be raised from the water- 
logged soil surface. Thus, the seedlings will present best results for survival and development. This method can also be used to restore other wetland forests.

- To the nurserymen who produce seedlings of Swamp Forest typical species, it would be better to leave them acclimating in tanks whose water level rises gradually and it is kept in the border of the plant bag or tube for at least 50 days.

- To those restorers who intend to plant in the dry season of the year, it would be better to order the nursery seedlings beforehand, to guarantee the properly tillage size in this period, which it is not so common.

- In the rainy seasons, do not perform the conventional tillage which is the opening of pits at the soil level. This procedure does not produce good results on seedling tillage for the restoring of wet areas.

\section{References}

Attanasio, C. M., S. Gandolfi, S., Zakia M. J B., Junior J. C. T. V., \& Paula Lima, W. (2012). A importânicia das áreas ripárias para a sustentabilidade hidrológica do uso da terra em microbacias hidrográficas. Bragantia, Campinas, 71, 493-501. http://dx.doi.org/10.1590/S0006-87052013005000001

Agnew, L. J., Lyon, S., Gérard-Marchant, P., Collins, V. B., Lembo, A. J., Steenhuis, T. S., \& Walter, M. T. (2006). Identifying Hydrologically Sensitive Areas: Bridging the Gap between Science and Application. Environmental Management, 78, 63-76. http://dx.doi.org/10.1016/j.jenvman.2005.04.021

Allan, C. J., Vidon, P., \& Lowrance, R. (2008). Frontiers in Riparian Zone Research in the 21st Century. Hydrological Processes, 22, 3221-3222. http://dx.doi.org/10.1002/hyp.7086

Burkhard, B., Petrosillo, I., \& Constanza, R. (2010). Ecosystem Services_Bridging Ecology, Economy and Social Sciences. Ecological Complexity, 7, 257-259. http://dx.doi.org/10.1016/j.ecocom.2010.07.001

Campos, M. C. R., Tamashiro, J. Y., Assis, M. A., \& Joly, C. A. (2011). Florística e fitossociologia arbóreo da transição Floresta Ombrófila Densa das Terras Baixas-Floresta Ombrófila Densa Submontana do Núcleo Picinguaba/PESM, Ubatuba, sudeste do Brasil. Biota Neotrop, 11. http://dx.doi.org/10.1590/S1676-06032011000200030

Carvalho, P. E. R. (1994). Espécies florestais brasileiras: Recomendações silviculturais, potencialidades e uso da madeira. Colombo: EMBRAPA-CNPF/SPI, 640p.

Collins, K. E., Doscher, C., Rennie, H. G., \& Ross, J. G. (2013). The Effectiveness of Riparian "Restoration” on Water Quality-A Case Study of Lowland Streams in Canterbury, New Zealand. Restoration Ecology, 21, 40-48. http://dx.doi.org/10.1111/j.1526-100X.2011.00859.x

Galindo, A., Rubio, R., Murgueitio, R., Calle, DE., Bothia, J. L., Rubio, P., Cardozo, A., \& Caroprese, J. (2012). Una innovación technological para la siembra of árboles en las sabanas inundables Orinoco la: Silvotermiteros the mounds. FEDEGAN Letter, 66-70.

Gorenstein, M. R., Borges, P. C. A., \& Poletto, R. S. (2006). Comportamento silvicultural de seis espécies nativas na re-vegetação da mata ciliar do Córrego Barreiro em Garça, SP. Revista Científica Eletrônica de Engenharia Florestal, 112.

Ivanauskas, N. M., Rodrigues, R. R., \& Nave, A. G. (1997). Aspectos ecológicos de um trecho de floresta de brejo em Itatinga, SP: Florística, fitossociologia e seletividade de espécies. Revista Brasileira de Botânica, São Paulo, 20, $139-153$. http://dx.doi.org/10.1590/S0100-84041997000200005

Joly, C. A., Spigolon, J. R., Lieberg, S. A., Salis, S. M., Aidar, M. P. M., Metzger, J. P. W., Zickel, C. S., Lobo, P. C., Shimabukuro, M. T., Marques, M. C. M., \& Salino, A. (2004). Projeto Jacaré-Pepira: O desenvolvimento de um modelo de recomposição da mata ciliar com base na florística regional. In R. R. Rodrigues, \& H. F. Leitão Filho (Eds.), Matas Ciliares: Conservação e recuperação (2nd ed., pp. 271-288). São Paulo: Edusp/FAPESP.

Joly, C. A., \& Crawford, R. M. M. (1982). Variation in Tolerance and Metabolic Response to Flooding in Some Tropical Trees. Journal of Experimental Botany, 33, 799-809. http://dx.doi.org/10.1093/jxb/33.4.799

Kozlowski, T. T. (1984). Responses of Woody Plants to Flooding. In T. T. Kozlowski (Ed.), Flooding and Plant Growth (pp.129-163). London: Academic Press.

Lorenzi, I. H. (2008). Árvores Brasileiras: Manual de identificação e cultivo de plantas arbóreas do Brasil. Nova Odessa, SP: Instituto Plantarum.

Marques, M. C. M., \& Joly, C. A. (2000). Estrutura e dinâmica de uma população de Callophyllum brasiliense Cambess em florestas higrófila do sudeste do Brasil. Revista Brasileira de Botanica, 23, 107-112.

Marques, M. C. M., \& Joly, C. A. (2002). Germinação e crescimento de Callophyllum brasiliense Cambess (Clusiaceae), uma espécie típica de florestas inundadas. Acta Botanica Brasilica, 14, 120-133.

Marques, M. C. M., Silva, S. M., \& Salino, A. (2003). Florística e estrutura do component arbustivo-arbóreo de uma floresta higrófila da bacia do Rio Jacaré-Pepira, SP, Brasil. Acta Botanica Brasilica, 17, 495-506. 
http://dx.doi.org/10.1590/S0102-33062003000400002

Matthews, G. V. T. (2013). The Ramsar Convention on Wetlands: Its History and Development. Gland, Switzerland: Ramsar Convention Secretariat, 90.

Naiman, R. J., \& Décamps, H. (1997). The Ecology of Interfaces: Riparian Zones. Annual Review Ecological System, 28, 621-658. http://dx.doi.org/10.1146/annurev.ecolsys.28.1.621

Oliveira-Filho, A. T., \& Ratter, J. A. (1995). A Study of the Origin of Central Brazilian Forests by the Analysis of Plant Species Distribution Patterns. Edinburg Journal of Botany, 52, 141-194. http://dx.doi.org/10.1017/S0960428600000949

Paschoal, M. E. S., \& Cavassan, O. (1999). A flora arbórea da mata de brejo do ribeirão do pelintra, Agudos-SP. Naturalia, 24, 153-170.

Rodrigues, R. R., \& Gandolfi, S. (2004). Conceitos, tendências e ações para a recuperação de florestas ciliares. In R. R. Rodrigues, \& H. F. Leitão Filho (Eds.), Matas Ciliares: Conservação e recuperação (2nd ed., pp. 235-247). São Paulo: Edusp/FAPESP.

Rodrigues, R. R., \& Leitão-Filho, H. F. (Eds.) (2004). Matas Ciliares: Conservação e recuperação (2 ed.). 1 reimpr, São Paulo: Edusp/FAPESP, 235-247.

Rodrigues, R. R., Lima, R. A. F., Gandolfi, S., \& Nave, A. G. (2009). On the Restoration of High Diversity Forests: 30 Years of Experience in the Brazilian Atlantic Forest. Biological Conservation, 142, 1242-1251.

Rodrigues, R. R., Gandolfi, S., Nave, A. G., Aronson, J., Baker, T. E., Vidal, C. Y., \& Brancalion, P. H. S. (2011). Large-Scale Ecological Restoration of High-Diversity Tropical Forests in SE Brazil. Forest Ecology and Management, 261, 1605-1613.

Setzer, A. W., \& Malingreau, J. P. (1996). The Monitoring of Vegetation Fires in the Tropics: Towards a Global Product. In J. Levine (Ed.), Biomass Burning and Global Change (pp. 25-39). Cambridge: MIT Press.

Sztutman, M., \& Rodrigues, R. R. (2002). O mosaico vegetacional numa área de floresta continua da planície litorânea, Parque Estadual da Campina do Encantado, Pariquera-Açu, SP. Revista Brasileira de Botânica, 25, 161-176. http://dx.doi.org/10.1590/S0100-84042002000200005

Teixeira, A. P., \& Assis, M. A. (2005). Caracterização florística e fitossociológica do componente arbustivo-arbóreo de uma floresta paludosa no município de Rio Claro (SP), Brasil. Revista Brasileira de Botânica, 28, 467-476. http://dx.doi.org/10.1590/S0100-84042005000300005

Teixeira, A. P., Assis, M. A., Siqueira, F. R., \& Casagrande, J. C. (2008). Tree Species Composition and Environmental Relationships in a Neotropical Swamp Forest in Southeastern Brazil. Wetlands Ecology and Management, 16, 451-461.

Toniato, M. T. Z., Leitão Filho, H. F., \& Rodrigues, R. R. (1998). Fitossociologia de um remanescente de floresta higrófila (mata de brejo) em Campinas, SP. Revista Brasileira de Botânica, 21, 197-210. http://dx.doi.org/10.1590/S0100-84041998000200012

Torres, R. B., Matthes, L. A. F., \& Rodrigues, R. R. (1994). Florística e estrutura do componente arbóreo de mata de brejo em Campinas, SP. Revista Brasileira de Botânica, 17, 189-194.

Zamith, L. R., \& Scarano, F. R. (2006). Restoration of the Sandbank Sandy Coastal Plain in Brazil: Survival and Growth of Planted Woody Species. Restoration Ecology, 14, 87-94. http://dx.doi.org/10.1111/j.1526-100X.2006.00108.x

Zedler, J. B. (2003). Wetlands at Your Service: Reducing Impacts of Agriculture at the Watershed Scale. Frontiers in Ecology and the Environment, 1, 65-72. http://dx.doi.org/10.1890/1540-9295(2003)001[0065:WAYSRI]2.0.CO;2 